九州大学学術情報リポジトリ

Kyushu University Institutional Repository

\title{
New Certation Gene on the First Linkage Group Found by Inter-subspecific Hybridization of Cultivated Rice
}

Nakagahra, Masahiro

Laboratory of Plant Breeding, Faculty of Agriculture, Kyushu University

Omura, Takeshi

Laboratory of Plant Breeding, Faculty of Agriculture, Kyushu University

Iwata, Nobuo

Laboratory of Plant Breeding, Faculty of Agriculture, Kyushu University

https://doi.org/10.5109/22853

出版情報 : 九州大学大学院農学研究院紀要. 18 (3)，pp. 157-167，1974-06. Kyushu University バージョン：

権利関係 : 


\title{
New Certation Gene on the First Linkage Group Found by Inter-subspecific Hybridization of Cultivated Rice
}

\author{
Masahiro Nakagahra*, Takeshi Omura and Nobuo Iwata \\ Laboratory of Plant Breeding, Faculty of Agriculture, \\ Kyushu University, Fukuoka \\ (Received February 18, 1974)
}

\begin{abstract}
In the hybrid progenies between Japanese testers and exotic varieties of rice plants, the segregation-distortions of four marker genes belonging to the first linkage group, wx, $d p_{1}$, alk and ws, were found. From the genetic behaviors of the four characters in $F_{1}, F_{2}, F_{3}, F_{4}$ and $B_{1} F_{1}$, it was concluded that the segregation-distortion was not caused by any of the abnormality of germination of $F_{1}$ seeds, duplication of genes themselves, complementary fertility genes and cytoplasmic factors, but caused by the linkage between the marker genes and a certation gene, gametophyte gene $\left(g a_{4}\right)$. The recombination value between ga, and wx was calculated on each of the all cross combinations. Based on the linkage intensities, the pollinating ability of ga, against $g a_{4}^{+}$pollen grains at the time of pollination of $F_{1}$ plants was also calculated. The presence of gametophyte genes shows at least distinct information regarding reproductive isolation, and the fact that the phylogenetic differentiation widely took place in Oryra sativa species.
\end{abstract}

\section{INTRODUCTION}

The segregation-distortion in inter-subspecific hybrid population of rice plants has been observed on many marker genes. Among them, the distorted segregation of wx (glutinous or waxy endosperm) and C (chromogen for anthocyanin coloration) has been well recognized (Oka,1953a, b, c; Mizushima and Kondo, 1959, etc.). Two hypotheses have been proposed as to the genetic mechanism operating in this phenomenon, one is caused by the complementary fertility genes (Oka, 1953b), the other by genic or chromosomal duplication (Mizushima and Kondo, 1960 ; Kondo, 1963).

In the previous papers (Nakagahra, 1972 ; Nakagahra et al., 1972), the distorted segregation of three genes belonging to the eleventh linkage group, bc (brittle culm), dl (drooping leaf) and ck (chlorina leaf), was reported with the causal genetic mechanism different from the above hypotheses.

The present study deals with the newly found segregation-distortion of three genes in addition to wx, all of which belong to the first linkage group, chromosome 6 .

* Present address : National Institute of Agricultural Science, Hiratsuka, Kanagawa. 


\section{MATERIALS AND METHODS}

The genetic testers of the Japanese rice plants (juponica) were used as one parent possessing four recessive genes, wx (waxy or glutinous endosperm), $d p_{1}$ (depressed palea), alk (alkali reaction) and ws (white striped leaf), all of which show single recessive inheritance and belong to the first linkage group, the chromosome 6 (Iwata and Omura, 1971). The other parental varieties shown in Table 1 are originated in Continental China, Assam, India, Nepal and Sri Lanka. They are so-called indica types except for HO 1021. The variety of HO 1021 is one of the collections from Nepal and is considered to be juponica.

Table 1. Parental varieties tested.

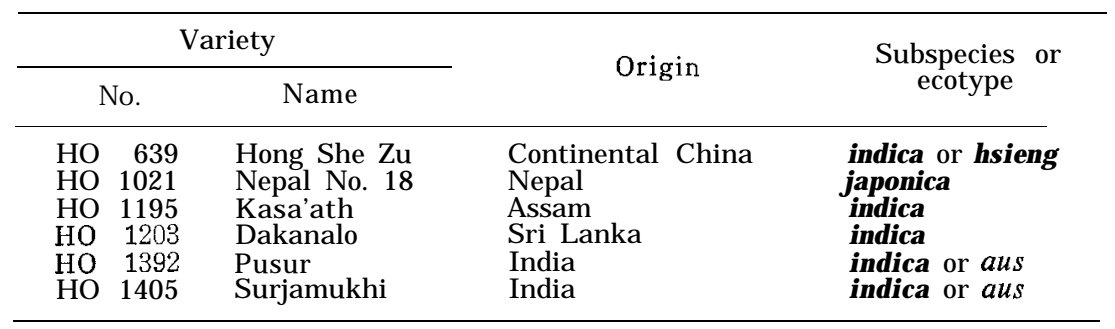

In the hybrid progenies between a Japanese genetic tester and a foreign variety, examinations were made in the following items; 1) $F_{1}$ fertilities of seeds and pollen grains, 2) segregation mode of $w x$ in $F_{1}$ pollen grains, 3) $F_{2}$ segregation modes of $\mathrm{wx}, d p$, alk and ws, 4) relationship between the extent of the distorted segregation and semi-sterility and 5) segregations of $\mathrm{wx}$ in $\mathrm{F}_{3}$, $\mathrm{F}_{4}$ and $\mathrm{B}_{4} \mathrm{~F}_{1}$.

\section{RESULTS}

\section{1) Breeding of $F_{1}$ plants and their fertility}

If the hybrid semi-sterility is observed in an $F_{1}$ plant of the cross of Japanese tester with a foreign variety and there is the linkage between its causal gene so-called complementary fertility genes and a genetic marker gene, the segregation of the marker would be distorted. In the present study, an apparent semisterility was recognized only in the cross combination of the Japanese tester with $\mathrm{HO}$ 639. In $\mathrm{F}_{1}$ hybrids between a Japanese tester and the other foreign varieties, their seed and pollen fertilites were nearly normal (Table 2).

All of the $F_{1}$ plants were normal in appearance but vigorous in growth as compared with the parental varieties. $F_{2}$ seeds obtained from each of $F_{1}$ plants germinated as good as normal seeds, and $\mathrm{F}_{2}$ plants survived normally and produced enough $F_{3}$ seeds. The difference in fitness of $F_{2}$ plants seemed to be negligible.

\section{2) Distorted segregation in $\mathbf{F}_{2}$}

In all of the four marker characters, the segregation modes in $F_{2}$ population were skewed from the expectation of single recessive inheritance. The actual 
Table 2. Seed and pollen fertilities and ratio of waxy pollen grains in $F_{1}$ anthers of the crosses of the Japanese tester (wx wx) with the foreign varieties $\left(w x^{+} w x^{+}\right)$.

\begin{tabular}{cccc}
\hline $\begin{array}{l}\text { Foreign } \\
\text { variety }\end{array}$ & \multicolumn{2}{c}{$F_{1}$ fertility $(\%)$} & $\begin{array}{c}\text { Frequency of } \\
\text { wx pollen }\end{array}$ \\
\cline { 2 - 3 } & Seed & Pollen & $(\%)$ \\
HO $639 "$ & 41.4 & 48.3 & 49.8 \\
HO 1021 & Fertile & Fertile & $-\overline{7}$ \\
HO 1195 & 94.9 & 92.4 & 49.7 \\
HO 1203 & 97.4 & Fertile & 49.8 \\
HO 1392 & 84.2 & Fertile & \\
HO 1405 & 89.4 & Fertile & 50.5 \\
\hline
\end{tabular}

1): HO 639 having wxwx genotype was crossed with the Japanese tester of wxwx genotype.

2) : Fertility of pollen grains was complete, but large and small grains were mixed.

Table 3. Distroted segregation of $w x$ for glutinous endosperm in $\mathrm{F}_{2}$ of Japanese tester $(\mathrm{wxwx}) \times$ foreign variety $\left(w x^{+} w x^{+}\right)$.

\begin{tabular}{|c|c|c|c|c|c|c|}
\hline \multirow{2}{*}{\multicolumn{2}{|c|}{$\begin{array}{l}\text { Foreign } \\
\text { variety }\end{array}$}} & \multicolumn{3}{|c|}{ Segregation in $F_{2}$} & \multirow{2}{*}{$\underset{\text { wx }}{\text { Frequency of }}$} & \multirow{2}{*}{$\chi^{2}$ for $3: 1$} \\
\hline & & \multirow{2}{*}{$\frac{\mathrm{wx}+}{1,402}$} & \multirow{2}{*}{$\frac{w x}{18}$} & \multirow{2}{*}{$\begin{array}{r}\text { Total } \\
1,994\end{array}$} & & \\
\hline $\mathrm{HO}$ & 6391 & & & & 27.7 & $23.4 * * *$ \\
\hline $\mathrm{HO}$ & 1021 & 116 & 210 & 134 & 13.4 & 9. $6^{* *}$ \\
\hline $\mathrm{HO}$ & 1195 & 1,145 & & 1,355 & 19.1 & $65.2^{* * *}$ \\
\hline $\mathrm{HO}$ & 1203 & 518 & 122 & 640 & 16.3 & 12. $0 * * *$ \\
\hline $\mathrm{HO}$ & 3.392 & 1,536 & 299 & 1,835 & & $74.2^{* *}$ \\
\hline $\mathrm{HO}$ & 1405 & 232 & 55 & 287 & 19.2 & $5.2^{*}$ \\
\hline
\end{tabular}

*** and $* * *$ indicate significance at 5, 1 and $0.1 \%$ level, respectively.

3) Since HO 639 has wxwx genotype, the segregation mode was shown by the result of the cross, Japanese tester $\left(w x^{+} w x^{+}\right) \times$HO 639 (wxwx). In this case, the frequency of the genotypes from the Japanese tester ( $w x^{+}$ $w x^{+}$) is reduced, it means that the increment of wxwx plants is the same phenomenon as that of the other cases.

segregation modes of $w x$ are given in Table 3 . The "deficit type" of distorted segregation were observed in all cross combinations except for the cross of the Japanese tester with HO 639. Since the foreign variety HO 639 has wxwx genotype, it was crossed with the Japanese tester of $w x^{+} w x^{+}$genotype. In this case, the segregation-distortion in $F_{2}$ appeared as "excess type." This increase in the frequency of wxwx genotype means that the frequency of $w x^{+} w x^{+}$, the same genotype as the Japanese tester, was decreased in the $F_{2}$ population. Therefore the excess type seems to be the same phenomenon as the deficit type. The frequencies of $\mathrm{wx}$ in the populations of deficit type varied between 13.4 and 19.2 percent, so that their decrement from normal frequency $(25 \%)$ ranged from 11.6 to 5.8 percent (Table 3).

In $d p$, character, the reduction of proportion of the recessive plants was similar to that of wx. Namely, the frequencies of $d p_{1}$ plants varied between 13.4 and 19.2 percent (Table 4), but the extent of distortion was rather stronger than that of wx in respective cross.

Table 5 gives the results of another marker gene, alk. The frequency of 
Table 4. Distorted segregation of $d p_{1}$ for depressed palea in $\mathrm{F}_{2}$ of Japanese tester $\left(d p_{1} d p_{1}\right) \mathbf{X}$ foreign variety $\left(d p_{1}^{+} d p_{1}^{+}\right)$.

\begin{tabular}{|c|c|c|c|c|c|c|}
\hline \multirow{2}{*}{\multicolumn{2}{|c|}{$\begin{array}{l}\text { Foreign } \\
\text { variety }\end{array}$}} & \multicolumn{3}{|c|}{ Segregation in $F_{2}$} & \multirow{2}{*}{$\begin{array}{c}\text { Frequency of } \\
d p_{1} \\
(96)\end{array}$} & \multirow{2}{*}{$\chi^{2}$ for $3: 1$} \\
\hline & & \multirow[t]{2}{*}{$d p_{1}^{+}$} & \multirow[t]{2}{*}{$d p_{1}$} & \multirow[t]{2}{*}{ Total } & & \\
\hline HO & 639 & & & & & \\
\hline $\mathrm{HO}$ & 1021 & 672395 & 61 & 824456 & 18.4 13.4. & $18.9 * 4 * 32,9 * 4 \%$ \\
\hline $\mathrm{HO}$ & 1195 & 1,653 & 76 & 1,922 & 14.0 & $124.1 * * *$ \\
\hline $\mathrm{HO}$ & 1203 & 448 & 128 & 524 & 14.5 & 30. $a^{* * *}$ \\
\hline $\mathrm{HO}$ & 1392 & 800 & & 928 & 13. a & $62.2^{* * *}$ \\
\hline $\mathrm{HO}$ & 1405 & 232 & 55 & 287 & 19.2 & $5.2^{*}$ \\
\hline
\end{tabular}

Table 5. Distorted segregation of alk for alkali reaction in $F_{2}$ of Japanese tester (alkalk) $\mathbf{X}$ foreign variety $\left(a l k^{+} a l k^{+}\right)$.

\begin{tabular}{|c|c|c|c|c|c|}
\hline \multirow{2}{*}{$\begin{array}{l}\text { Eoreign } \\
\text { variety }\end{array}$} & \multicolumn{3}{|c|}{ Segregation in $F_{2}$} & \multirow{2}{*}{ uency of } & \multirow{2}{*}{$\chi^{2}$ for $3: 1$} \\
\hline & $a l k^{+}$ & alk & Total & & \\
\hline $\begin{array}{l}\text { HO } \\
\text { HO } 1195639\end{array}$ & 748224 & $\begin{array}{r}11- \\
87\end{array}$ & 835235 & $\begin{array}{r}4.7 \\
10.4\end{array}$ & $51.7 * * *$ \\
\hline $\begin{array}{ll}\text { HO } & 1203 \\
\text { HO } & 1392 \\
\text { HO } & 1405\end{array}$ & $\begin{array}{l}255213 \\
978\end{array}$ & $\begin{array}{r}30 \\
100\end{array}$ & $\begin{array}{r}3453033 \\
1,078\end{array}$ & $\begin{array}{r}14: 9.95 \\
9.3\end{array}$ & $\begin{array}{r}20.3 * * 36.8 * * * \\
142.1 * * * *\end{array}$ \\
\hline
\end{tabular}

Table 6. Distorted segregation of $w s$ for white striped leaf in $F_{2}$ of Japanese tester ( $\boldsymbol{w} s w s) \mathrm{X}$ foreign variety $\left(\boldsymbol{w} s^{+} \boldsymbol{w} s^{+}\right)$.

\begin{tabular}{|c|c|c|c|c|c|}
\hline \multirow{2}{*}{$\begin{array}{l}\text { Foreign } \\
\text { Varlety }\end{array}$} & \multicolumn{3}{|c|}{ Segregation in $F_{2}$} & \multirow{2}{*}{$\begin{array}{c}\text { Frequency of } \\
\text { ws } \\
(\%)\end{array}$} & \multirow{2}{*}{$x^{2}$ for $3: 1$} \\
\hline & $w s^{+}$ & ws & Total & & \\
\hline HO 639 & 983 & 129 & 1,112 & 11.6 & $106.5 *$ **⿻一⿰冫⿰亅⿱丿丶丶 \\
\hline HO 1195 & 1,386 & 222 & 1,608 & 13.8 & $107.5^{* * *}$ \\
\hline HO 1203 & 500 & 110 & 610 & 18.0 & 15. $8^{* * *}$ \\
\hline HO 1392 & 231 & 61 & 292 & 20.9 & 2.6 \\
\hline HO 1405 & 206 & 48 & 254 & 18.1 & $5.0^{*}$ \\
\hline
\end{tabular}

the recessive individuals was the lowest in all marker genes used, ranging from 4.7 to 14.5 percent.

In the fourth marker, ws, the distorted segregation was also observed, but its reduction was not so notable on the average as compared with that of alk (Table 6).

Thus, the apparent segregation-distortion was recognized in all the marker genes of all cross combinations. However, it was simultaneously confirmed that the extent of distortion varied according to difference in the kind of marker genes.

Meanwhile, the gene analysis in the cross between Japanese testers has given the sequence of the four genes being $w x$-dp-alk-ws. The wx locus links very closely with $d p$, and alk links with wx and ws with the recombination values of approximately 25 and 14 percent, respectively (Nagamatsu and Omura, 1962 ; Kudo, 1968).

Then, the relation between gene sequence and the distorted segregation is shown in Fig, 1. The reduction in the frequency of alk individuals is larger 


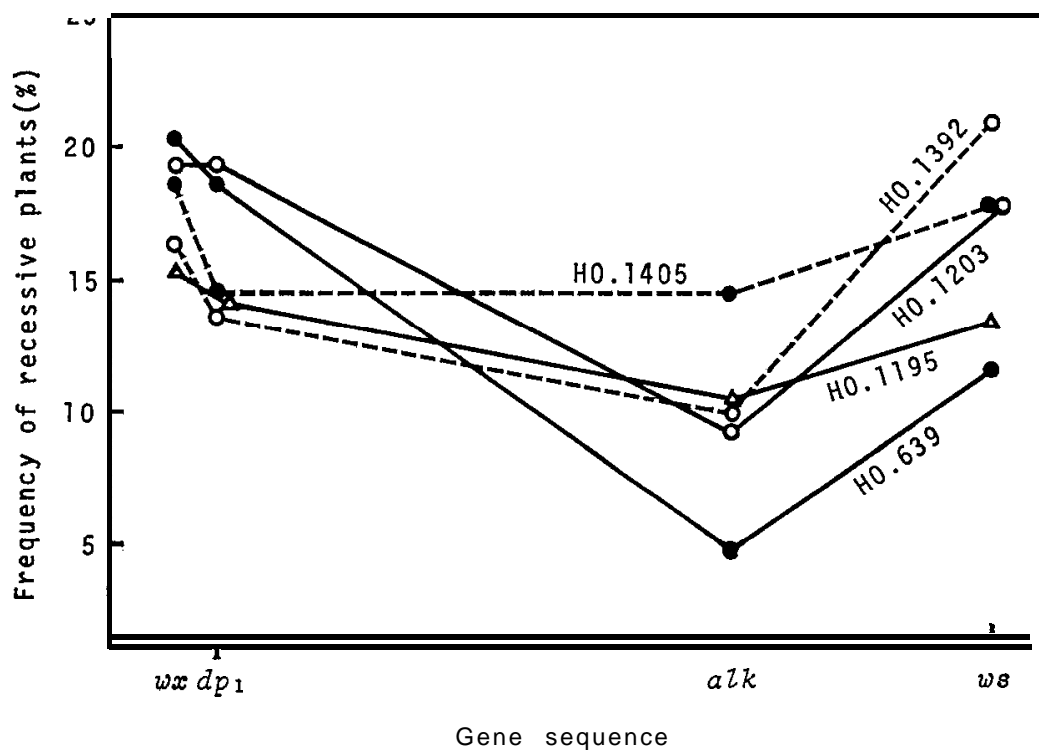

Fig. 1. Relationship between gene sequence and distorted segregation of the four genes on the first linkage group.

than that of any other markers, moreover, the degree of decrease in each character tended to become stronger according as its locus is far distant from alk locus. This fact suggests the genic control of the segregation-distortion.

3) Effect of fertility on the distorted segregation

The hybrid-sterility observed in the inter-subspecific cross breeding causes the distorted segregation of marker genes (Oka, 1953a, b). In the present study, semi-sterility was observed in the progenies in and after $\mathrm{F}$, generations of the cross of HO 639 with a Japanese marker line, and after $F_{2}$ of the cross between a Japanese tester and each of HO 1392 and HO 1405. Assuming that there are some correlation between the semi-sterility and the segregationdistortion in the above cases, it was examined whether or not the segregation for $w x$ genotype in $F_{3}$ lines is skewed by the degree of the sterility of their parental $\mathrm{F}_{2}$ plants.

Table 7 shows that the segregation-distortion of wx gene was not directly related to the semi-sterility of $\mathrm{F}_{2}$ individuals. The complementary fertility genes can thus be considered to be independent of the distortion, so that there must be a different factor controlling the phenomenon.

\section{4) Genetic mechanism of the distorted segregation}

It now appears, as mentioned above, that none of the following three factors, viz. 1) sterile factors named complementary fertility genes, 2) differential fitness between phenotypes of a marker and its wild alleles, and 3) diversity in the expressiveness of respective marker characters, are causal in the mechanism inducing the distorted segregation. Additionally, the segregation-distortion was not affected in pattern and extent by the reciprocal crosses. Therefore, cyto- 
Table 7. The relationship between fertility and frequency of glutinous plants in $F_{2}$ segregations of the cross, Japanese tester (wxwx) $\times$ foreign variety $\left(w x^{+} w x^{+}\right)$.

\begin{tabular}{|c|c|c|c|c|c|c|c|c|}
\hline \multirow{2}{*}{\multicolumn{2}{|c|}{ Variety }} & \multirow{3}{*}{$\begin{array}{c}\text { No. of } \\
\text { crosses }\end{array}$} & \multirow{4}{*}{$\begin{array}{r}\begin{array}{r}\text { Fertility } \\
\text { of } \mathrm{F}_{2}{ }^{1}\end{array} \\
-\mathrm{N} \\
\mathrm{SS}\end{array}$} & \multirow{2}{*}{\multicolumn{3}{|c|}{ No. of genotypes }} & $\begin{array}{c}\text { Frequency } \\
\text { of wx+wx } \\
(\%)\end{array}$ & \multirow{2}{*}{$\begin{array}{c}\chi^{2} \text { for } \\
\text { independence }\end{array}$} \\
\hline & & & & & & & & \\
\hline $\mathrm{HO}$ & 63921 & & & $\frac{\mathrm{wx}+\mathrm{wx}+}{12}$ & $w x+w x$ & \multirow{2}{*}{$\begin{array}{c}\text { Total } \\
55 \\
69\end{array}$} & 782 & \\
\hline & & & & 14 & 55 & & 79.7 & 0.000 \\
\hline & & & $\mathrm{S}+\mathrm{HS}$ & 25 & 89 & 114 & 78.1 & $(\mathrm{~N}=\mathrm{S}+\mathrm{HS})$ \\
\hline & & & $\begin{array}{l}\text { Total } \\
\mathrm{N}\end{array}$ & $\begin{array}{l}51 \\
14\end{array}$ & $\begin{array}{r}187 \\
19\end{array}$ & 238 & 78.6 & \\
\hline $\mathrm{HO}$ & 1392 & 2 & SS & 29 & 42 & 33 & 57.6 & \\
\hline & & & $\begin{array}{l}\text { S+HS } \\
\text { Total }\end{array}$ & 5699 & $\begin{array}{r}84 \\
144\end{array}$ & $\begin{array}{l}71 \\
141243\end{array}$ & $\begin{array}{l}59.2 \\
60.059 .3\end{array}$ & $\begin{array}{c}0.003 \\
(\mathrm{~N}-\mathrm{S}+\mathrm{HS})\end{array}$ \\
\hline \multirow{3}{*}{$\mathrm{HO}$} & \multirow{3}{*}{1405} & \multirow{3}{*}{1} & \multirow{3}{*}{$\begin{array}{l}\mathrm{N} \\
\mathrm{SS}+\mathrm{S}+\mathrm{HS} \\
\text { Total }\end{array}$} & 35 & 65 & \multirow{3}{*}{$\begin{array}{l}109 \\
105 \\
205\end{array}$} & \multirow{3}{*}{$\begin{array}{l}65.9 \\
63.4\end{array}$} & \multirow{3}{*}{$\begin{array}{c}0.099 \\
(\mathrm{~N}-\mathrm{SS}+\mathrm{S}+\mathrm{HS})\end{array}$} \\
\hline & & & & 40 & 65 & & & \\
\hline & & & & 75 & 130 & & & \\
\hline
\end{tabular}

1) The symbol of N, SS, S and HS indicates normal fertility (fertile more than $80 \%$ ), partial sterility (60-80\%), semi-sterility (30-60\%) and high sterility (less than $30 \%$ in fertility), respectively.

2) HO 639 having wxwx genotype was crossed with the Japanese tester of $w x^{+} w x^{+}$ genotype.

plasmic factors also can be considered to have no particular influence on the distortion.

From these facts it would be very reasonable to assume that a certation gene is the main causal factor to induce the segregation-distortion as reported in the previous papers (Nakagahra, 1972; Nakagahra et al., 1972); in which the segregation-distortion of the three markers belonging to the eleventh linkage group (chromosome 5) were dealt with. Further evidence to justify this assumption will be described under. When a marker gene links with such a certation gene as a gametophyte gene, the $F_{1}$ male gametes possessing a marker gene will pollinate less to female gametes on account of the strongness of their linkage relationship. Consequently, the frequency of marker plants in an $F_{2}$ population will be expected to become lower than normal frequency of 25 percent. In $F_{3}$ lines derived from the heterozygous $F_{2}$ plants, three different types of segregation modes should appear. The first is the "deficit type," the same segregation as $F$, the second is the normal one showing the Mendelian expectation, and the third is the "excess type" produced as a result of recombination between a marker gene and a gametophyte gene.

Fig. 2 gives an actual result of the $\mathrm{F}_{3}$ observation in the cross of the Japanese tester $(w x)$ with HO 1405. Many lines of deficit and normal types appeared, and a few lines of excess type were newly observed.

In the $F_{4}$ lines derived from the heterozygous $F_{3}$ line of the deficit type, the same results as in the $F_{3}$ generation should be expected. On the contrary, in the case of the excess type, most of the lines should be excess and normal types. This expectation was sufficiently justified by the experimental results. The former case is shown in Fig. 3. Many lines of deficit type and several lines of normal type were observed, but excess type expected as a recombinant was not recognized, presumably because the number of $F_{4}$ lines used was not enough 


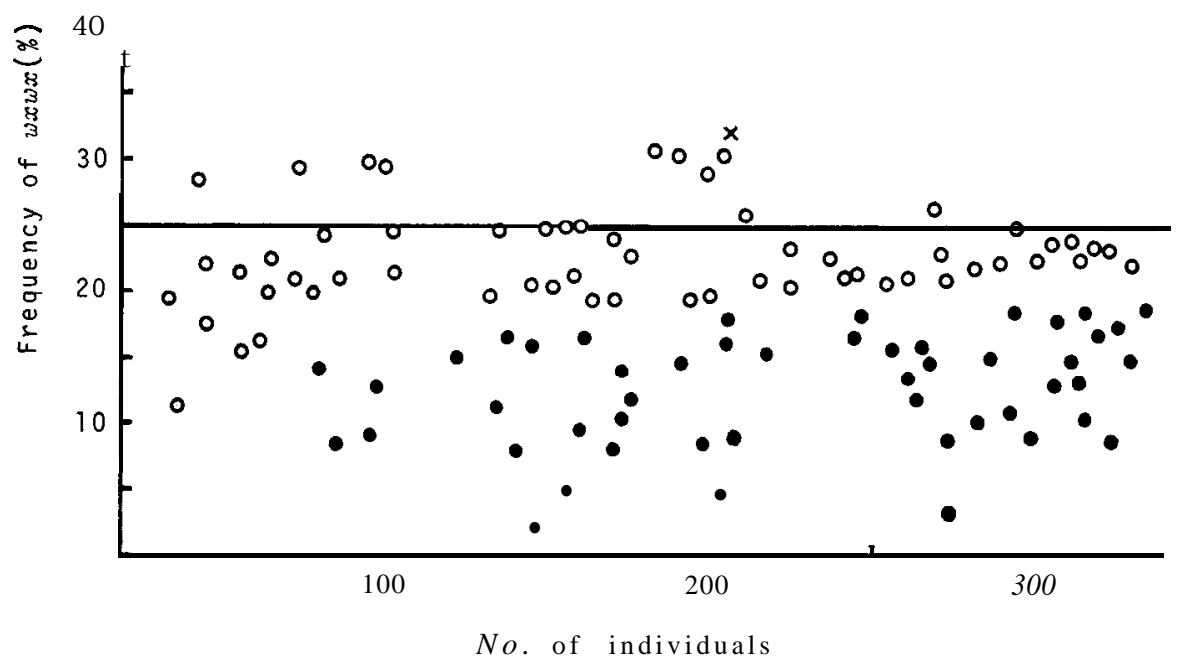

Fig. 2. Segregation pattern of $w x$ in $F_{3}$ lines derived from $F_{2}$ plants $\left(w x^{+} w x\right)$ of the cross of Japanese tester (wxwx) $\times$ HO $1405\left(w x^{+} w x^{+}\right)$, foreign variety.

$\supset$ : Normal type, $\bullet \quad$ : Deficit type and $x$ : Excess type of segregations.

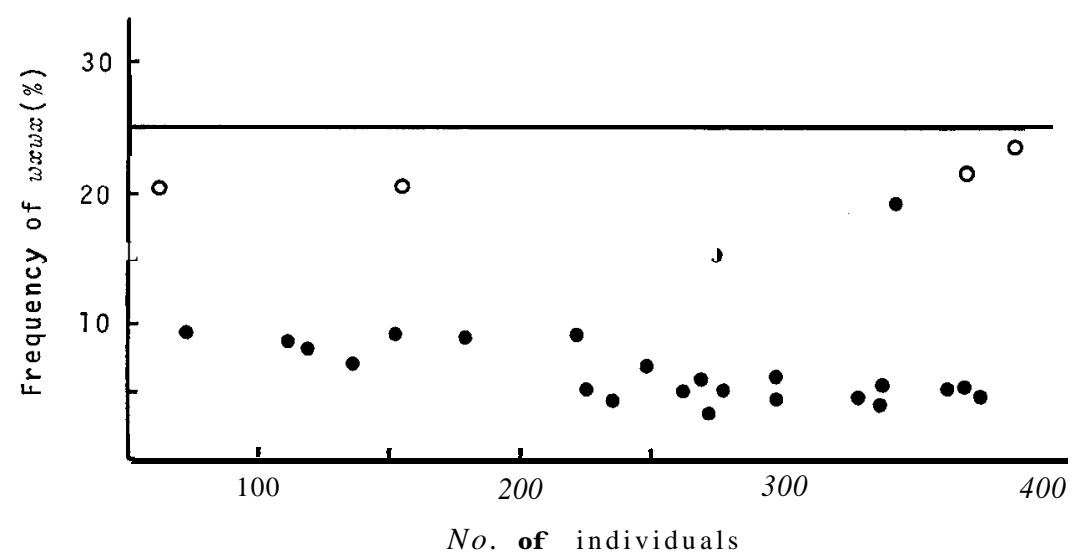

Fig. 3. Segregation pattern of $\mathrm{wx}$ in $\mathrm{F}_{4}$ lines derived from the $\mathrm{F}_{3}$ line showing the deficit type of segregation. 0 : Normal type and 0 : Deficit type of segregations.

to contain the lines of the excess type. The latter case is shown in Fig. 4. Both the excess and the normal type were recognized in many $F_{4}$ lines, but the deficit type was observed in only two lines.

In addition, an other experiment has also been performed to prove our hypothesis. If the segregation-distortion in $\mathrm{F}_{2}$ is induced by the linkage between a marker gene and a gametophyte gene, the distortion will also be observed in 


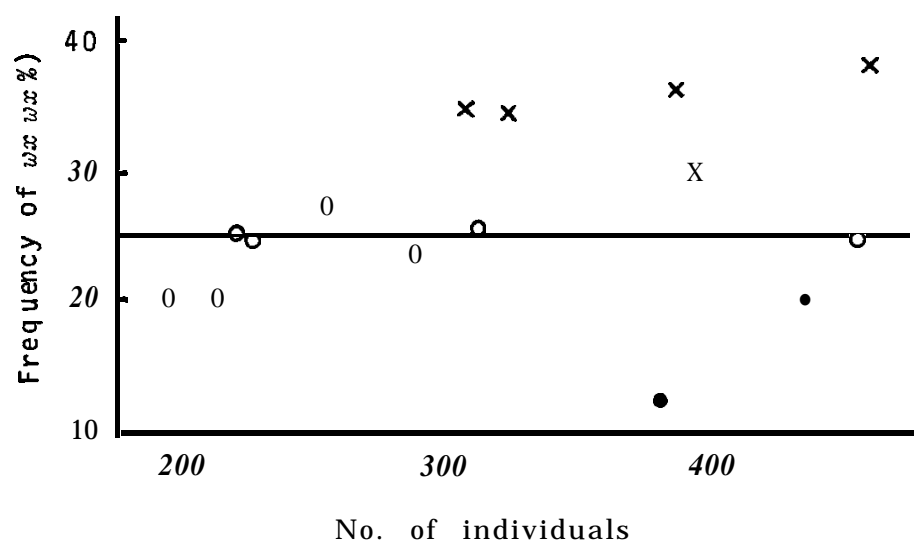

Fig. 4. Segregation pattern of $w x$ in $F_{4}$ lines derived from the $F_{3}$ line showing the excess type of segregation. 0 : Normal type, 0: Deficit type and $x$ : Excess type of segregations.

Table 8. Distorted segregation of $w x$ in $\mathrm{B}_{1} \mathrm{~F}_{1}$ compared with its estimation from $\mathrm{F}_{2}$.

\begin{tabular}{|c|c|c|c|c|c|c|c|c|c|}
\hline \multirow{2}{*}{\multicolumn{2}{|c|}{$\begin{array}{l}\text { Foreign } \\
\text { variety }\end{array}$}} & \multirow[t]{2}{*}{ Item } & \multicolumn{3}{|c|}{ Segregation in $B_{1} F_{1}$} & \multirow{2}{*}{$\begin{array}{c}\text { Frequency } \\
\text { of } w x \\
(\%)\end{array}$} & \multirow{2}{*}{$\begin{array}{c}\chi^{2} \text { for } \\
1: 1\end{array}$} & \multirow{2}{*}{$\begin{array}{l}\chi^{2} \text { for } \\
\text { Hetero- } \\
\text { geneity }\end{array}$} & \multirow{2}{*}{$\begin{array}{l}\text { Distortion } \\
\text { type in } \mathrm{F}_{2}\end{array}$} \\
\hline & & & $w x^{+}$ & $\begin{array}{c}w x \\
-60\end{array}$ & Total & & & & \\
\hline \multirow[t]{2}{*}{$\mathrm{HO}$} & \multirow[t]{2}{*}{639} & Observation & 42 & 60.6 & \multirow{3}{*}{$\begin{array}{l}102 \\
102.0 \\
175 \\
175.0\end{array}$} & 58.8 & 3.176 & \multirow{2}{*}{0.006} & \multirow{2}{*}{ Excess } \\
\hline & & & & 53 & & & & & \\
\hline \multirow[t]{2}{*}{$\mathrm{HO}$} & \multirow[t]{2}{*}{1195} & Observation & 122 & 54.3 & & 30.3 & $27.206^{* * * *}$ & & \\
\hline & & Estimation & 120.7 & & \multirow{2}{*}{$\begin{array}{l}90 \\
90.0\end{array}$} & & $25,194 * * *$ & 0.020 & Deficit \\
\hline $\mathrm{HO}$ & 1405 & $\begin{array}{l}\text { Observation } \\
\text { Estimation }\end{array}$ & $\begin{array}{l}49 \\
48.5\end{array}$ & $\begin{array}{l}41 \\
41.5\end{array}$ & & $\begin{array}{l}45.6 \\
46.1\end{array}$ & $\begin{array}{l}0.711 \\
0.544\end{array}$ & 0.005 & Deficit \\
\hline
\end{tabular}

$B_{1} F_{1}$ segregation when the $F_{1}$ plant is used as a paternal parent.. The actual segregation modes of $\mathrm{wx}$ in $\mathrm{B}_{1} \mathrm{~F}_{1}$ and their expectation, which is estimated from $F_{2}$ data by the equation given in the previous paper (Nakagahra, 1972), are shown in Table 8. The results show a good fit between the observed and the calculated segregation mode.

These evidences described above certainly reconfirm that the segregationdistortion in the present case is caused by the existence of a gametophyte gene linked with the marker genes examined. Then, the present gametophyte gene is temporarily symbolized as $\boldsymbol{g a}$,. The genotypes concerned with wx and $\boldsymbol{g} \boldsymbol{a}$,, therefore, can be estimated as follows: HO 1021, HO 1195, HO 1203, HO 1392 and HO 1405 are expressed as $w x^{+} g a_{4}^{+} / w x^{+} g a_{4}^{+}$, and their cross pairs, the Japanese testers have the genotype of $w x g a_{4} / w x g a_{4}$. On the contrary, in the cross combination of the Japanese tester $\mathrm{x}$ HO 639, the genotype of the tester parent can be put on $w x^{+} g a_{4} / w x^{+} g a_{4}$ and that of HO $639 w x g a_{4}^{+} / w x g a_{4}^{+}$.

5) Calculation of the recombination value between $g a_{4}$ and $w x$, and of the pollinating ability of $g a$,

As the recombination value between $\mathrm{wx}$ and $g a$, cannot be calculated in $\mathrm{F}_{2}$, it is done from the frequency of segregation types in $F_{3}$ lines. When the 
recombination value between $g a_{4}$ and wx is put on $p$, and the number of lines exhibiting deficit, normal and excess types of segregation in $F_{3}$ lines is expressed as $\mathbf{a}, \mathbf{b}$ and $\mathbf{c}$ respectively, the recombination value is given by the following equations (Nakagahra et al., 1972). In the case of the cross of $w x g a_{4} / w x g a_{4} \times$ $w x^{+} g a_{4}^{+} / w x^{+} g a_{4}^{+}$,

$$
\mathbf{p}=(b+2 c) / 2(a+b+c)
$$

and in the case of the cross of $w x^{+} g a_{4} / w x^{+} g a_{4} \times w x g a_{4}^{+} / w x g a_{4}^{+}$,

$$
\mathbf{p}=(2 a+b) / 2(a+b+c)
$$

The standard deviation $\left(s_{p}\right)$ is

$$
s_{p}=\sqrt{p(1-p) / 2(a+b+c)}
$$

When the recombination value is given by the above formulae, the pollinating ability (k) can be estimated by the following equations (Nakagahra et al., 1972). In the case of the deficit type of distortion,

$$
k=(p-2 f) /(2 f-(1-p)\}
$$

and in the case of the excess type of distortion,

$$
k=\{(1-p)-2 f\} /(2 f-p)
$$

where $f$ is the frequency of recessive individuals in $\mathrm{F}_{2}$ population.

The recombination values and pollinating ability of ga, calculated by the above formulae are shown in Table 9. The recombination values between ga, and wx ranged from 11.8 to 42.9 percent. The pollinating ability of pollen grains with ga, against those with $g a_{4}^{+}$differed considerably among the parental foreign varieties, but all of them, except for HO 1405, took lower value than 0.5.

Table 9. Recombination value (p) between $g a_{4}$ and $w x$, and pollinating ability (k) of $g a$,.

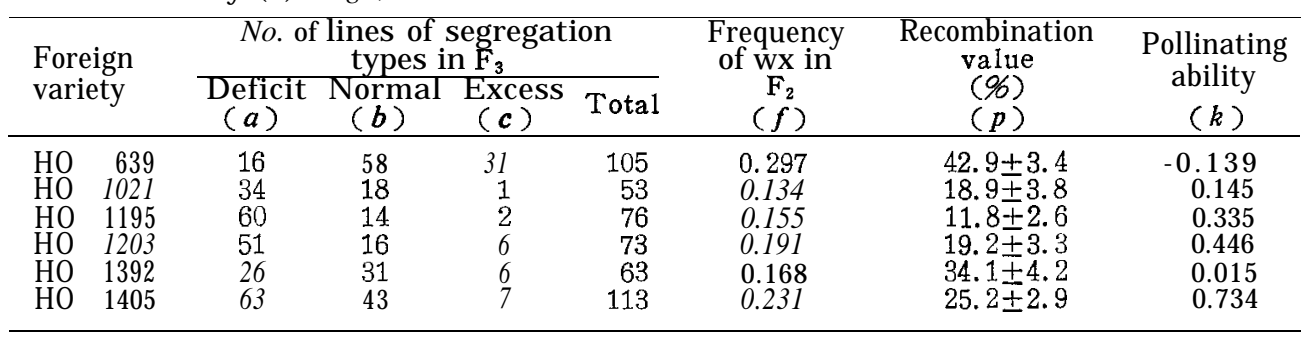

\section{DISCUSSION}

Two marker genes belonging to the first linkage group, wx and $\mathrm{C}$, have been known to show the segregation-distortion in the progenies of inter-subspecific hybrid of rice plants (Chao, 1928; Oka, 1953a, b, c; Mizushima and Kondo, 1959, 1960, 1961; Kondo, 1963 ; Kudo, 1968). In the present study, other genes such as $d p_{1}$, alk and ws, all belong to the same linkage group, were supplemented as the new distortion markers.

Concerning the genetic mechanism of the segregation-distortion, Oka (195313) proposed a hypothesis that the distorted segregations of wx and C were 
caused by the linkage between these genes and one of the complementary fertility genes, gametic development genes. In the present paper, however, segregation-distortion has appeared differently, indicating that the gene frequency is not concerned with the hybrid sterility. Consequently, it was concluded that the gene frequency of the marker genes belonging to the first linkage group was influenced by a certation gene, named gametophyte gene which linked with the marker genes. The existence of a gametophyte gene in rice plants was first reported by Iwata et al. (1964), and the distorted segregations of genes located on the eleventh linkage group were clearly illustrated by the existence of gametophyte genes (Nakagahra, 1972; Nakagahra et al., 1972). Therefore, the gametophyte gene may be generally accepted as a causal factor of the segregationdistortion. The gametophyte gene is distinguishable from the duplicate sterility genes by having the pollinating ability of pollen grains, but more detailed relationship between them should be clarified.

Because the degree of segregation-distortion was stronger in alk than in any other genes (Fig. 1), it may be said that $g a_{4}$ is located near the alk locus. Moreover, as shown in Table 9, the recombination value between wx and ga, and the pollinating ability of $g a_{4}$ against $g a_{4}^{+}$differed considerably among cross combinations. This fact seems to suggest that "ga," contains some genes, though it was tentatively regarded as single gene. However, it has been well known that the recombination value between certain two genes, and the pollinating ability of a certain gametophyte gene varied on account of the cross combination and environmental factors. Therefore, it remains obscure whether " $\mathrm{ga}_{4}$ " is a gene or genes.

The species of cultivated rice plant, Oryza sativa L., has a great number of varieties different in morphological, physiological and biochemical characteristics. The presence of various ecotypes shows that rice plants have a long history of the origin of the species. Therefore, the existence of the gametophyte and the complementary fertility genes must be recognized as one of the results of occurrence of wide differentiation. Further, these genes would give the strong influence on the formation of new ecotypes or subspecies as one of the factors operating on the reproductive isolation.

\section{ACKNOWLEDGEMENT}

The authors are most grateful to Prof. Emeritus T. Nagamatsu and Prof. T. Katayama for their kind advices and encouragement throughout this work. Thanks are also due to Dr. K. Hayashi, National Institute of Agricultural Science, for his kind reading and criticisms of the manuscript.

\section{REFERENCES}

Chao, L. F. 1928 The disturbing effect of the glutinous gene in rice on a Mendelian ratio. Genetics, $13: 191-225$

Iwata, N., T. Nagamatsu and T. Omura 1964 Abnormal segregation of waxy and apiculus coloration by a gametophyte gene belonging to the first linkage group in rice. Jap. J. Breed., 14: 33-39 (in Japanese with English summary) 
Iwata, N. and T. Omura 1971 Linkage analysis by reciprocal translocation method in rice plants (Oryza sativa L.) II. Linkage groups corresponding to the chromosomes 5, 6, 8, 9, 10 and 11. Sci. Bull. Fac. Agr. Kyushu Univ., 25: 137-155 (in Japanese with English summary)

Kondo, A. 1963 Chromosome pairing in hybrids of cultivated rice estimated by the form of segregation of characters. Ikushugaku Saikin no Shimpo (Advances in Breeding), 4: 15-25 (in Japanese)

Kudo, M. 1968 Genetical and thremmatological studies of characters, physiological or ecological, in the hybrids between ecological rice groups. Bull. Natl. Inst. Agr. Sci. Ser. D., No. 19: 1-84 (in Japanese with English summary)

Mizushima, U. and A. Kondo 1959 Fundamental studies on rice breeding through hybridization between Japanese and foreign varieties. I. An anomalous mode of segregation of apiculus anthocyanin pigmentation observed in a hybrid between a Japanese and an Indian variety. Jap. J. Breed., 9: 212-218 (in Japanese with English summary)

Mizushima, U. and A. Kondo 1960 Fundamental studies on rice breeding through hybridization between Japanese and foreign varieties. II. Structural difference of chromosomes between a Japanese and an Indian variety proved by anomalous mode of segregation in apiculus anthocyanin pigmentation in their hybrid. Jap. J. Breed., 10: I-9 (in Japanese with English summary)

Mizushima, U. and A. Kondo 1961 Fundamental studies on rice breeding through hybridization between Japanese and foreign varieties. 111. Anomalous modes of segregation of glutinous character observed in hybrids between varieties of remote origin. Jap. J. Breed., 11: 253-260 (in Japanese with English summary)

Nagamatsu, T. and T. Omura 1962 Linkage study of the genes belonging to the first chromosome in rice. Jap. J. Breed., 12: 331-236

Nakagahra, M. 1972 Genetic mechanism of the distorted segregation of marker genes belonging to the eleventh linkage group in cultivated rice. Jap. J. Breed., 22: 232-238

Nakagahra, M., T. Omura and N. Iwata 1972 Gametophyte genes and their loci on the eleventh linkage group of cultivated rice. Jap. J. Breed., 22: 305-312

Oka, H. I. 1953a The mechanism of sterility in the intervarietal hybrid. Phylogenetic differentiation of the cultivated rice plant. VI. Jup. J. Breed., 2: 217-224 (in Japanese with English summary)

Oka, H. I. $1953 \mathrm{~b}$ Gene analysis of intervarietal hybrid sterility and certation due to certain combinations of gamete-development-genes in rice. Phylogenetic differentiation of the cultivated rice plant. VIII. Jap. J. Breed., 3: 23-30 (in Japanese with English summary)

Oka, H. I. 1953c Influence of intervarietal hybrid sterility on segregation ratios in rice. Phylogenetic differentiation of the cultivated rice plant. IX. Jap. J. Breed., 3: 31-39 (in Japanese with English summary) 